\title{
FDI (Foreign Direct Investments) as Correlate of Rwanda Economic Development
}

\author{
Umutoni Flora1, Ze Tian², Joseph Obiora Ezezue ${ }^{3}$ \\ ${ }^{1}$ Department of Business Administration, Business School of Hohai University Jiangning Campus, Nanjing, China \\ ${ }^{2}$ Low Carbon Economy Research Institute, Hohai University Changzhou Campus, Changzhou, China \\ ${ }^{3}$ Plot 243/244 Transobibia Layout, Awka, Nigeria \\ Email: floramulan@gmail.com, tianze21@126.com, obioraezezue@gmail.com
}

How to cite this paper: Flora, U., Tian, Z. and Ezezue, J.O. (2020) FDI (Foreign Direct Investments) as Correlate of Rwanda Economic Development. Open Journal of Business and Management, 8, 783-795. https://doi.org/10.4236/ojbm.2020.82048

Received: February 11, 2020

Accepted: March 17, 2020

Published: March 20, 2020

Copyright (c) 2020 by author(s) and Scientific Research Publishing Inc. This work is licensed under the Creative Commons Attribution International License (CC BY 4.0).

http://creativecommons.org/licenses/by/4.0/ (c) (i) Open Access

\begin{abstract}
This study examines the foreign direct investment as correlation to the economic development of Rwanda. The research was influenced by three investigation questions while using the time series approach. The secondary data used was collected from the stock exchange of Rwanda. The data was then analyzed using simple linear regression and Pearson products moment correlation with the application of SPSS, 23 (Statistical packages for social sciences). The findings showed that there's a critical relationship between the exchange rate and direct foreign investment in Rwanda. The study concludes that direct foreign investment poses a considerable effect on the market share and importation of Rwanda. The study suggests that the government of Rwanda needs to develop a more friendly business environment and economic policies that will virtually attract FDI into every economic sector of the country.
\end{abstract}

\section{Keywords}

FDI, Economic Growth, Market Share, Importation, Exchange Rate

\section{Introduction}

For the past 40 years, FDI (foreign direct investments) in African region has been naturally chaotic and erratic. FDI's volume has relatively increased in the past 40 years in the entire African region. There have been sudden increases accompanied by sudden decreases in the sequence of progress in successive years. Additionally, there has been a decline in the movement of foreign direct investment to the African region as compared to other global regions that have been developing for the past several years. Therefore, this is why the increase is con- 
sidered to be relative (Williams, 2017) [1]. FDI (Foreign Direct Investments) refer to any direct investments by any profitable corporation in another nation. According to Mallampally and Sauvant (2011) [2], FDI are defined as any investment by multi-national companies in foreign nations with the aim of managing production activities and controlling assets in those nations. FDI play a development and exceptional role in international business by offering a company with new marketing channels and markets for their services or products. For the foreign company or host country that gets the investment, FDI provide it with a new source of capital, technologies, organizational technologies, products, process as well as modern management procedures. All these factors are believed to be partly responsible for the country's economic development and growth. FDI are significant, not only to the developing nations like Rwanda, as well as the developed countries (Pradhan, 2009) [3].

According to Morris (2016) [4], the ROI (return on investment) on foreign direct investment in every region on the globe has been fascinating such that all the developing nations show the greatest possibility of ROI in their nations and should nonetheless draw more capital from foreign countries. The average ROI on foreign direct investment in the African region is $22.6 \%$; the average rate of primary sector for the past years was $21 \%$; the average rate of secondary sector was $19.2 \%$; the average rate for tertiary sector was $13.8 \%$ and the average rate for the other industries was $23.5 \%$. This clearly indicates that foreign direct investment is not concentrated within the primary sector anymore, which was previously the case. In 2002, the FDI of Rwanda in primary sector was a bit above $10 \%$, manufacturing approximately $15 \%$ and the services near to $20 \%$. In 1995 , the FDI of Egypt was at $45 \%$ in services, $4 \%$ in primary sector, and $47 \%$ in manufacturing. Ndupu (2017) [5] declared that FDI is made by external resources, which include technology, capital, marketing, and managerial expertise. All these factors create a significant impact on the production capabilities of the host country.

Based on the current gross domestic products (GDP) level, the prosperity of government policies to stimulate the productive economic base is largely dependent on the government's ability to manage sufficient amount of FDIs comprising of capital, technological, and managerial resources to increase the current production capacities (Olayiwola \& Okodua, 2009) [6]. Formerly, the government of Rwanda attempted to provide a healthy business climate and generous taxation incentives to foreign investors, although the outcome was not sufficiently promising. Rwanda still needs foreign support in form of technical, entrepreneurial, and managerial skills that are often accompanied by FDIs. Thus, this research seeks to analyze FDI in correlation to the economic development of Rwanda.

\subsection{Objectives of This Study}

The extensive objective of the research is to analyze FDI in correlation to the development of Rwandan economy. This study specifically aims to; 
1) Analyze the effect of FDI on the market share of Rwanda,

2) Analyze the effect of FDI on the importation of Rwanda,

3) Establish the connection between the exchange rate of Rwanda and FDI.

\subsection{Research Questions}

Some of the research questions that guided the research include;

1) To what magnitude does FDI affect the market share in Rwanda?

2) How does FDI impact the importation of Rwanda?

3) To what magnitude does FDI affect the exchange rate in Rwanda?

\subsection{Research Hypotheses}

From the hypothesis stated below, hypotheses I \& II will be achieved using simple linear regression while hypothesis III will be achieved using Pearson product moment correlation.

The null hypothesis that guided this research include:

$\mathrm{H}_{\mathrm{o}}$ : FDI doesn't have a considerable impact on the market share of Rwanda,

$\mathrm{H}_{\mathrm{o} 2}$ : FDI doesn't have a considerable impact on the importation of Rwanda,

$\mathrm{H}_{\mathrm{o}}$ : There is no considerable relationship between the Exchange rate and FDI in Rwanda.

\section{Literature Review}

\subsection{Conceptual Framework}

\subsubsection{FDI (Foreign Direct Investments)}

According to Wilson (2007) [7], FDI (Foreign direct investments) refers to the investments made by an individual or company in another nation with the aim of making profit, either by acquiring assets/property in another nation or initiating business activities, for example, controlling business interests or ownership in foreign firms. The link between economic growth and FDI (foreign direct investments) is a properly-researched matter in development of economic literature, as well as empirically and theoretically. In a broader view, FDI (foreign direct investments) comprises the flow of expertise, technology, and capital into a host nation (Mwilima, 2013) [8]. FDI is formally defined as "the investments made for acquisition of lasting interests in organizations operating outside the investor's economy" (IMF, 2003) [9]. Concerned countries, international organizations, and researchers have increasingly acknowledged the significance that foreign capital has on economic growth. In this active age of globalization, liberation, and privatization, foreign direct investment has surfaced as a significant form of worldwide flow of capital. The World Bank, acknowledging the significance of investments without borders, has committed its 2005 report on World Development (2011) towards the problem of investment and trade, extensively discussing the significance of flow of foreign capitals on the economic development of host nations. As per the World Bank, "a few nations have developed without being free to engage in trades" (Ogunleye, 2010) [10]. 
Typically, there's a great concurrence on the significance of understanding that causes the movement of foreign direct investments. Nonetheless, there is a continuing debate concerning the benefits of openness. This discussion has been inspired by the current economic crises of some countries located in Southeast Asia. Fast and substantial movements of temporary portfolio investments that occurred in these nations were greatly blamed for those crises. However, several observers concur to differentiate foreign direct investment from the short-term (temporary) portfolio investments since Foreign Direct Investments are long-term investments, thus making it challenging to overturn (Lankhuizen, 2009) [11]. Therefore, acknowledging the significance of openness in matters regarding economic development, a rising number of nations have embraced more liberal procedures towards foreign capital flow. For this reason, the inflow of FDI to developing nations increased to a global GDP of 3\% in 2001 from $0.1 \%$ in 1970 (World Bank, 2005).

\subsubsection{Exchange Rate}

Exchange rate can be referred to as that price at which the country's currency is exchanged for the currency of other countries. Some of the factors that affect the exchange rate of a country include: 1) inflation rate, 2) political stability, 3) general economic state, 4) governance quality, 5) interest rate, 6) internal harmony, 7) trade balance, and 8) high intensity of openness in the behavior of administrators and leaders. In finance, the exchange rates (also referred to as forex rate, foreign exchange rates, Agio, FX rates, or ER) between two currencies refer to the rates at which a currency is traded for the other currency. Additionally, it is considered to be the value/price of a nation's currency as compared to the currency of another country (Ogwulu, 2011) [12]. Therefore, the exchange rate has 2 components, the foreign currency and domestic currency. Additionally, it can either be quoted indirectly or directly. The forex rate or foreign exchange is also referred to as the currency quotation. Moreover, exchange rate can either be floating or fixed. The floating forex rates are determined by the market mechanism of demand/supply while the fixed forex rates are determined by the country's central bank.

\subsubsection{Market Shares}

The presence of diseconomy and economy of scale indicates that small companies suffer because they lack economy of scale while large companies enjoy considerable cost benefits because of the economy of scale. Concurrently, if the firm's size becomes too big, the company may start to suffer for diseconomy of scale that tends to cancel out the merits of a large size. In addition to contributing to profitability, the market share might also be detrimental. According to Sheth \& Sisodia (2012) [13], companies with more than $40 \%$ market shares lose their benefits from scope and scale and also experience decreased performance. The PMS-based study does not disclose whether profitability eventually decreases at extremely high levels of market share as a result of the diseconomy of scale. 
On the contrary, experience economy results from the linked cost reductions and cumulative experience because of accumulated learning and production. Many studies have documented the presence of the experience curves (Yanopoulos, 2014) [14]. However, it has also become possible that larger cumulative volume does not instantly result in lower costs, even though there should be an intentional effort to exploit the probability of reducing cost (Yannopoulos, 2014) [14].

\subsubsection{Imports}

Imports can be illustrated as services or goods that are brought into a nation from another country. The term "import" is obtained from the term "port", because goods are usually shipped through boats to foreign nations. Imports and exports form the basis of international trade. The balance of trade of a country becomes more negative if the value/price of imports getting into a country is higher than the value/price of its exports (Baro, 2008) [15]. According to Sheffrin (2013) [16], import is identified as the foreign goods or services that are bought by a country's residents. Residents include; the government, businesses, and citizens. Imported goods can either be shipped or hand-carried on a plane in the personal luggage. If the goods are produced in foreign countries and then sold to the domestic residents, it will be referred as imports. Although most countries probably import goods/services that cannot be produced by domestic industries as cheaply or efficiently, they might also import commodities or raw materials that might not be available within the nation's territory. For instance, most nations import oil since they are not able to produce sufficient amount to meet its demand or they are not capable of producing the oil domestically. Materials and goods that are less costly to import are often dictated by tariff schedules and free trade treaties. According to Carbaugh (2014) [17], dependence on the imports from the cheaper labour locations and free trade treaties are accountable for a major percentage of the declination of manufacturing jobs. Free trade introduces the capability to import materials and goods from cheaper zones of production in the globe and minimizes the dependence of locally made goods. Countries usually start by developing trade protectionism, thus protecting their firms from international competition for some time. They increase taxes (tariffs) on imports, which makes them more costly. However, this was among the factors that caused the Great Depressions.

\subsection{Theoretical Framework}

\section{Technology Spillover Theory}

The technology spillover theory was proposed by Kinoshita (1998) [18]. This theory suggested that spillover of technology to textile companies in the host economy is illustrated in 4 channels through which the spillover of technology into domestic textile companies can possibly affect the output of the domestic textile companies through worldwide integration. These include the spreading drawback effects, training effect, and competition effect, forward and backward linkages. 
Through the spreading limitation effect, technology spillover is backed by Kokko (1994). To explain the transmittable limitation effect in connection to textile firms and globalization, it was disputed that there is a difference in technological levels between domestic and foreign textile companies. Through direct connection with foreign variation, local textile companies can observe and, thus, become profitable. This occurs through the labor revolution from foreign textile companies to the local textile companies, in which foreign firms' employees are hired by domestic companies and thereby coming with the knowledge of required technologies used by the former employers.

Competition effect might develop as the introduction of foreign companies, cause more profound industrial competition among the local textile companies and the local textile industries which compels them to become more effective in utilizing the existing resources and technologies. According to Kinoshita (1998) [18], the local textile companies might also be individually forced to introduce the required technologies, so as to sustain their market shares. The increased competition might have the ability to enhance the host country's welfare and get rid of monopolistic profits.

Furthermore, Kinoshita (1998) [18] explained the 'training effect' like the circumstance in which the on-the-job trainings might be offered by forming joint ventures with foreign partners, foreign suppliers, or buyers, causing vertical effects on the domestic textile companies. Local textile companies often train their employees to increase the quality of their products, thus giving them the competitive advantage that enables them to deal with entrants from other countries. On its own, arrival of the new technology may not affect the host country's productivity growth, unless the labor force develops the matching skills.

The relationship is enhanced by the presences of "regional content requirements", indicating that foreign companies have to buy certain proportion of the host country's intermediate inputs, rather than import from foreign suppliers. A connection comes into existence when affiliates abroad engage in business deals with local customers and suppliers. For example, when the scientific costs of transportation and communication in Europe is high, the MNCs (multinational corporations) usually opts to buy the local producers' intermediate goods; even in absence of local investment, thus forcing the local raw material suppliers to meet the demand for on-time deliveries, higher quality, and enhance more innovation (Kinoshita, 1998) [18].

\subsection{Empirical Review}

According to Taybout (2009) [19], a research on the effect of FDI on Kenya's market share was carried out. The research adopted the survey design approach and the obtained data was utilized as secondary data. Analysis of the collected data was then done using multiple regression method. The findings of the study showed that FDI significantly impacted the Kenya's market share.

A research on the relationship between FDI and imports by textile manufacturing companies in Nigeria was conducted by Anyanwu (2006) [20]. The re- 
search was undertaken using two Nigerian textile companies. Two research questions guided the research while survey questions were adopted. The gathered data was utilized as the secondary data and subsequently analyzed using the Pearson moments correlation. Findings of this research FDI impacted the country's importation significantly.

A research was carried out by Krugman \& Obsfeld (2011) [21] on the Indian manufacturing companies and Foreign Direct Investments (FDI). The research was accompanied with two research questions while the descriptive approach was adopted and the gathered data utilized as secondary data. Analysis of the collected data was conducted using regression. Findings of this study also revealed that there is a major relationship between the performances of a country's manufacturing firms and FDI.

Barrel and Pain (2014) [22] carried out a study on the influence of FDI in Kenya. The study was guided by two research questions and descriptive survey design was used. The data used was a secondary data collected through structured questionnaire. The data collected was analysed using linear regression. The findings revealed that FDI has a significant effect on economic development.

A research on the effect of FDI on the forex rate of Nigeria was also carried out by Folurunso \& Benjamin (2016) [23]. The duration of this research was sixteen years and it was guided by a single research question. The collected data was then utilized as secondary data and analyzed using the econometric techniques to model error correlation. The findings indicated that both economic integration measures affect economic growth significantly.

\section{Methodology}

\subsection{Research Design}

In this study, this study adopted time series data so as to obtain the relations between the dependent variables and the independent variables. The linear regression and person product moment correlation was used for the study with the aid of Statistical Package for Social Sciences (SPSS, 23).

\subsection{Source of Data}

The study will use only secondary data. These data would be sourced from Rwandan stock exchange and Statistical Bulletin Publications.

\section{Data Required}

The following data were required for analyzing data. The data include:

Data on market share for 10 years

Data on Foreign direct investment for 10 years

Data on exchange rate for 10 years

Data on importation for 10 years

\subsection{Sample Frame}

The data was collected on the variables of interest on Rwandan stock exchange. 
The sample point for the variable is from 2009 to 2018. These variables include, foreign direct investment manufacturing, labour force and inflation.

\subsection{Model Estimation}

The study will make use of linear regression and person moment correlation using statistical package for social science (SPSS).

\section{Equation}

To examine the impact of FDI with respect to economic growth, the following estimations are carried out:

$$
\mathrm{FDI}=f(\mathrm{MS}, \mathrm{EXCH}, \mathrm{IMP}) e_{t}
$$

This model is restated in econometric form as follows:

$$
\mathrm{FDI}=a_{0}+a_{1} \mathrm{MS}+a_{2} \mathrm{EXCH}+a_{3} \mathrm{IMP}+e_{t}
$$

where:

$$
\begin{aligned}
& e_{t}=\text { Stochastic or error term } \\
& \mathrm{MS}=\text { Market share } \\
& \mathrm{EXCH}=\text { Exchange rate } \\
& \mathrm{IMP}=\text { Importation }
\end{aligned}
$$

\section{Data Presentation and Analysis}

This chapter covered the presentation and analysis of data collected. This data as shown in Table 1 below, is meant for the empirical investigation. Here, regression and Pearson product moment correlation was run so as to be equipped for the interpretation and also to provide solution to the research questions in respect to FDI and economic development of Rwandan.

\section{FDI equation}

$$
\mathrm{FDI}=f(\mathrm{MS}, \mathrm{EXCH}, \mathrm{IMP}) e_{t}
$$

Table 1. Data presentation on import, exchange rate and market share.

\begin{tabular}{ccccc}
\hline Year & Import & Exchange rate & $\begin{array}{c}\text { Foreign Direct Investment } \\
\text { (FDI) (Billions) }\end{array}$ & Market share \\
\hline 2009 & 1415.24 & 758.65 & 241.02 & 1250.99 \\
2010 & 1253.62 & 760.99 & 250.5 & 1311.50 \\
2011 & 1262.17 & 763.32 & 119.1 & 1617.57 \\
2012 & 1247.33 & 765.64 & 255 & 1417.68 \\
2013 & 1590.95 & 767.94 & 257.6 & 1241.79 \\
2014 & 1491.73 & 770.24 & 314.7 & 1238.84 \\
2015 & 1643.05 & 770.24 & 223.3 & 1266.02 \\
2016 & 1580.53 & 774.82 & 266.3 & 1251.39 \\
2017 & 1443.51 & 9089.3 & 270.7 & 1273.95 \\
2018 & 1569.02 & 968.89 & 305.5 & 1621.35 \\
\hline
\end{tabular}

Sources: Rwandan Stock Exchange, Statistical Bulletin (Various issues), 2019. 
Test of hypothesis using statistical package for social science (SPSS, 23)

Level of significance $=0.05$

\section{Hypothesis I}

$\mathrm{H}_{\mathrm{o}}$ : There is no significant relationship between Foreign direct investment and Exchange rate in Rwandan

$\mathrm{H}_{1}$ : There is a significant relationship between Foreign direct investment and Exchange rate in Rwandan

\begin{tabular}{|c|c|c|c|}
\hline \multicolumn{4}{|c|}{ Descriptive Statistics } \\
\hline & Mean & Std. Deviation & $\mathrm{N}$ \\
\hline $\mathrm{EXCH}$ & 1619.0030 & 2625.56978 & 10 \\
\hline FDI & 250.3720 & 53.71787 & 10 \\
\hline \multicolumn{4}{|c|}{ Correlations } \\
\hline & & $\mathrm{EXCH}$ & FDI \\
\hline \multirow{3}{*}{$\mathrm{EXCH}$} & Pearson Correlation & 1 & 0.843 \\
\hline & Sig. (2-tailed) & & 0.004 \\
\hline & $\mathrm{N}$ & 10 & 10 \\
\hline \multirow{3}{*}{ FDI } & Pearson Correlation & 0.843 & 1 \\
\hline & Sig. (2-tailed) & 0.004 & \\
\hline & $\mathrm{N}$ & 10 & 10 \\
\hline
\end{tabular}

From the analysis above, it shows that the probability value (0.004) is less than the alpha value (0.05), the researchers therefore accept the alternative hypothesis and conclude that there is a significant relationship between Foreign direct investment and Exchange rate in Rwandan with a correlation value of 0.843 .

\section{Hypothesis II}

$\mathrm{H}_{\mathrm{o}}$ : Foreign direct investment does not have a significant impact on importation in Rwandan.

H1: Foreign direct investment has a significant impact on importation in Rwandan.

\begin{tabular}{|c|c|c|c|c|c|c|c|}
\hline \multicolumn{8}{|c|}{ Model Summary } \\
\hline \multirow[b]{2}{*}{ Model } & \multirow[b]{2}{*}{$\mathrm{R}$} & \multirow[b]{2}{*}{ R Square } & \multirow[b]{2}{*}{$\begin{array}{l}\text { Adjusted } \\
\text { R Square }\end{array}$} & \multirow[b]{2}{*}{$\begin{array}{l}\text { Std. Error of } \\
\text { the Estimate }\end{array}$} & \multicolumn{3}{|c|}{ Change Statistics } \\
\hline & & & & & $\begin{array}{c}\text { R Square } \\
\text { Change }\end{array}$ & F Change df1 df2 & $\begin{array}{c}\text { Sig. F } \\
\text { Change }\end{array}$ \\
\hline 1 & $0.724^{\mathrm{a}}$ & 0.879 & 0.777 & 51.61132 & 0.179 & 1.750 & 0.002 \\
\hline
\end{tabular}

a. Predictors: (Constant), import.

\begin{tabular}{ccccccc}
\hline \multicolumn{7}{c}{ ANOVA $^{\mathrm{b}}$} \\
\hline \multicolumn{1}{c}{ Model } & Sum of Squares & df & Mean Square & F & Sig. \\
\hline \multirow{3}{*}{1} & Regression & 4660.659 & 1 & 4660.659 & 1.750 & $0.002^{\mathrm{a}}$ \\
& Residual & $21,309.828$ & 8 & 2663.728 & & \\
& Total & $25,970.487$ & 9 & & & \\
& & & & & &
\end{tabular}

a. Predictors: (Constant), import; b. Dependent Variable: FDI. 


\begin{tabular}{|c|c|c|c|c|c|c|}
\hline \multicolumn{7}{|c|}{ Coefficients $^{\mathrm{a}}$} \\
\hline & \multirow{2}{*}{ Model } & \multicolumn{2}{|c|}{ Unstandardized Coefficients } & \multirow{2}{*}{$\begin{array}{c}\text { Standardized Coefficients } \\
\text { Beta }\end{array}$} & \multirow{2}{*}{$\mathrm{t}$} & \multirow{2}{*}{ Sig. } \\
\hline & & B & Std. Error & & & \\
\hline \multirow{2}{*}{1} & (Constant) & 32.446 & 165.558 & & 0.196 & 0.0050 \\
\hline & Import & 0.150 & 0.114 & 0.424 & 1.323 & 0.002 \\
\hline
\end{tabular}

a. Dependent Variable: FDI.

From the analysis, the regression equation is given as below:

$$
\text { FDI }=32.446+0.150 \text { import }
$$

The analysis shows that for every unit increase in FDI, importation increases by 0.150 . The analysis also shows that the probability value (0.002) is less than the alpha value (0.05) the researchers therefore reject the null hypothesis and conclude that Foreign direct investment has a significant impact on importation in Rwandan.

\section{Hypothesis III}

$\mathrm{H}_{\mathrm{o}}$ : Foreign direct investment does not have a significant impact on market share in Rwandan

$\mathrm{H}_{1}$ : Foreign direct investment has a significant impact on market share in Rwandan

\begin{tabular}{|c|c|c|c|c|c|c|c|c|c|}
\hline \multicolumn{10}{|c|}{ Model Summary } \\
\hline \multirow[b]{2}{*}{ Model } & \multirow[b]{2}{*}{$\mathrm{R}$} & \multirow[b]{2}{*}{$\begin{array}{c}\mathrm{R} \\
\text { Square }\end{array}$} & \multirow[b]{2}{*}{$\begin{array}{l}\text { Adjusted } \\
\text { R Square }\end{array}$} & \multirow[b]{2}{*}{$\begin{array}{l}\text { Std. Error of } \\
\text { the Estimate }\end{array}$} & \multicolumn{5}{|c|}{ Change Statistics } \\
\hline & & & & & $\begin{array}{l}\text { R Square } \\
\text { Change }\end{array}$ & $\begin{array}{c}\mathrm{F} \\
\text { Change }\end{array}$ & df1 & $\mathrm{df} 2$ & $\begin{array}{l}\text { Sig. F } \\
\text { Change }\end{array}$ \\
\hline 1 & $0.886^{\mathrm{a}}$ & 0.749 & 0.794 & 56.17938 & 0.149 & 0.614 & 2 & 7 & 0.001 \\
\hline
\end{tabular}

a. Predictors: (Constant), EXCH, MS.

\begin{tabular}{ccccccc}
\hline \multicolumn{7}{c}{ ANOVA $^{\mathrm{b}}$} \\
\hline & Model & Sum of Squares & df & Mean Square & F & Sig. \\
\hline \multirow{3}{*}{1} & Regression & 3877.631 & 2 & 1938.816 & 0.614 & $0.001^{\mathrm{a}}$ \\
& Residual & $22,092.855$ & 7 & 3156.122 & & \\
& Total & $25,970.487$ & 9 & & & \\
\hline
\end{tabular}

a. Predictors: (Constant), EXCH, MS; b. Dependent Variable: FDI.

\begin{tabular}{|c|c|c|c|c|c|c|}
\hline \multicolumn{7}{|c|}{ Coefficients $^{a}$} \\
\hline & \multirow{2}{*}{ Model } & \multicolumn{2}{|c|}{ Unstandardized Coefficients } & \multirow{2}{*}{$\begin{array}{c}\text { Standardized Coefficients } \\
\text { Beta }\end{array}$} & \multirow{2}{*}{$\mathrm{t}$} & \multirow{2}{*}{ Sig. } \\
\hline & & $\mathrm{B}$ & Std. Error & & & \\
\hline & (Constant) & 421.090 & 171.631 & & 2.453 & 0.0001 \\
\hline \multirow[t]{2}{*}{1} & MS & 0.129 & 0.125 & 0.364 & 1.030 & 0.007 \\
\hline & $\mathrm{EXCH}$ & 0.002 & 0.007 & 0.085 & 0.240 & 0.002 \\
\hline
\end{tabular}

a. Dependent Variable: FDI. 
From the analysis, the regression equation is given as below:

$$
\mathrm{FDI}=421.090+0.129 \mathrm{MS}
$$

The analysis shows that for every unit increase in FDI, market share increases by 0.129 . The analysis also shows that the probability value $(0.002)$ is less than the alpha value (0.05) the researchers therefore reject the null hypothesis and conclude that Foreign direct investment has a significant impact on market share in Rwandan

\section{Conclusions and Recommendations}

From the analysis above, the researchers conclude that there is a significant relationship between foreign direct investment and exchange rate in Rwandan. This shows that foreign direct investment has a great impact on Rwandan. The researchers therefore conclude that foreign direct investment has a significant impact on importation and market share in Rwandan.

\subsection{Recommendations}

The following recommendations are made to the Rwandan government;

1) The Rwandan government should increase its foreign direct investment so as to increase its exchange rate.

2) There is need for Rwandan government to increase its foreign direct investment so as to increase its market share.

3) The Rwandan government needs to embark on more capital projects, which will enhance the infrastructural facilities with which foreign investors can build on thereby increasing FDI.

4) The current indigenization policy should be pursued to the letter as a way of preventing absolute foreign ownership in the key sector of the economy.

\subsection{Limitation of the Study}

This study which focused on foreign direct investment as correlation to the economic development of Rwanda was faced with several challenges which include the challenges of sourcing for material during the research. The researchers also experienced the challenge of data collection as it was difficult for the researchers to obtain such relevant information.

\section{Conflicts of Interest}

The authors declare no conflicts of interest regarding the publication of this paper.

\section{References}

[1] Williams, M.I. (2017) Exchange Rate Determination, Foreign Investment Burden and External Debt Crisis I Less Developed Countries: Nigeria Experience. International Journal of Business and Economics Perspective, 2, 91.

[2] Mallampally, B.B. and Sauvant, A.Y. (2011) Dynamics Linkages among Foreign Di- 
rect Investment, Public Investment and Private Investment: Evidence from Turkey. Applied Econometrics and International Development, 5, 71-82.

[3] Pradhan, R.P. (2009) FDI-LED Growth Hypothesis in ASEAN 5 Countries: Evidence from Co Integrated Panel Analysis. International Journal of Business and Management, 14, 12-14. https://doi.org/10.5539/ijbm.v4n12p153

[4] Morris, D. (2016) Global Foreign Direct Investment Flows: The Role of Governance Infrastructure. World Development, 3, 18-19.

[5] Ndupu, R. (2017) FDI and Economics Development in African. The ADB/AERC International Conference in Accelerating African Development, Tunis, November 2017, 22-24.

[6] Olayiwola, S. and Okodua, L. (2009) Foreign Direct Investment, Non-Oil Export and Economic Growth in Nigeria: A Causality Analysis. Annual Conference on Africa, Lagos, 2009, 12-14.

[7] Wilson, H. (2007) Determinant of Foreign Direct Investment in Ethiopia: A Time Series Analysis. 4th International Conference on the Ethiopian Economy, Addis Ababa, 10-12 June 2007, 12-13.

[8] Mwilima, N. (2013) Foreign Direct Investment in Africa. African Labour Research Network. Labour Resources and Research Institute (LaRRi), African Social Observatory Pilot Project, 94.

[9] International Monetary Fund (2003) Foreign Private Investment in Developing Countries. A Study by the International Monetary Fund Research Department. Occasional Paper No. 33.

[10] Ogunleye, E.K. (2010) Exchange Rate Volatility and Foreign Direct Investment in Sub-Saharan African: Evidence from Nigeria and South Africa. African Centre for Economic Transformation. An Excerpt from a PHD Dissertation.

[11] Lankhuizen, M. (2009) Determinant of FDI: An Empirical Investigation into Sources of Attraction. Print Partner Ipskamp, Enshede.

[12] Ogwulu, D.F.W. (2011) In Search of FDI-Led Growth in Developing Countries. Ibero America Institute of Economic Research, Florida.

[13] Sheth, B.T. and Sisodia, G. (2012) The Determinant of Foreign Direct Investment: A Panel Study on AMU Countries. Liverpool Business School, Woolton.

[14] Yanopoulos, A. (2014) Determinant of Foreign Direct Investment in Nigeria: Political Factor Effect Revisited. http://www.Jmulti.de

[15] Baro, A. (2008) Effect of FDI Inflows on Host Country Economic Growth. Electronic Working Paper Series, Paper 0.58.

[16] Sheffrin, V. (2013) Foreign Direct Investment and Economic Growth in Transition Economies. South Eastern Europe Journal of Economics, 2, 97-110.

[17] Carbaugh, C.S. (2014) Foreign Direct Investment. Institute of Management Studies, Madura.

[18] Kinoshita, H. (1998) The Technology Spillover Theory of Host Economy.

[19] Taybout, S. (2009) Impact of Foreign Direct Investment on Market Share in Kenya. Journal of Social Science, 4, 44-45.

[20] Anyanwu, C. (2006) Relationship between Foreign Direct Investment and Importation Using Textile Manufacturing Firms in Nigeria. Economic Journal of Management, 5, 11-14.

[21] Krugman, E. and Obsfeld, V. (2011) Foreign Direct Investment and Performance of Manufacturing Companies in India. Journal of Social Science, 4, 44-45. 
[22] Barrel, R. and Pain, N. (2014) Foreign Direct Investment, Technical Change and Economic Growth within Europe. The Economic Journal, 107, 1770-1986. https://doi.org/10.1111/j.1468-0297.1997.tb00081.x

[23] Foluruns, D. and Benjamin, F. (2016) Impact of Foreign Direct Investment on Exchange Rate in Nigeria. Journal of Social Science, 4, 44-45. 